\title{
Cross-cultural validation of the educational needs assessment tool into Chinese for use in severe knee osteoarthritis
}

\author{
Huiwen Zhaol,* \\ Zhe Dong ${ }^{2, *}$ \\ Fei $\mathrm{Xie}^{3,4}$ \\ Guanxin Wang ${ }^{2}$ \\ Zhihua Wen ${ }^{5}$ \\ Lixia Zhang ${ }^{5}$ \\ Mwidimi Ndosi ${ }^{6,7}$ \\ Wen Luo'
}

'Joint Department, The 2nd Ward of Joint Surgery, Tianjin Hospital,

Tianjin, China; ${ }^{2}$ Medical Examination

Center, No 6 Hospital, Beijing, China;

${ }^{3}$ Nursing Experimental Teaching

Center, Tianjin Hospital,Tianjin, China;

${ }^{4}$ College of Nursing, Tianjin University

of Traditional Chinese Medicine,

Tianjin, China; ${ }^{5}$ Joint Department,

The Ist Ward of Joint Surgery, Tianjin

Hospital, Tianjin, China; ${ }^{6}$ Department

of Nursing, University of the West

of England, Bristol, UK; ${ }^{7}$ Academic

Rheumatology Unit, Bristol Teaching

Hospitals, Bristol, UK

*These authors contributed equally to this work
This article was published in the following Dove Press journal:
Patient Preference and Adherence

\begin{abstract}
Background: Patient education is an integral part of the management of osteoarthritis. The educational needs assessment tool (ENAT) was developed in the UK to help direct needs-based patient education in rheumatic diseases.
\end{abstract}

Aim: The aim of the study was to adapt and validate the ENAT into Chinese, for use in severe knee osteoarthritis (KOA).

Methods: This cross-cultural validation study took two phases: 1) adaptation of the ENAT into Chinese (CENAT) and 2) validation of the CENAT. The Construct validity was determined using factor analysis and criterion-related validity by comparing data from CENAT with data from different self-efficacy scales: patient-physician interactions scale (PEPPI-10), self-efficacy for rehabilitation outcome scale (SER), and the self-efficacy for exercise scale (SEE).

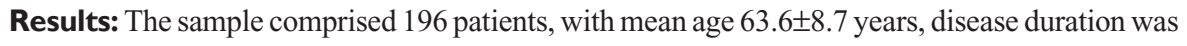
11.5 years, and $57.1 \%$ were female. The CENAT was found to have high internal consistency. The CENAT had weak correlations with the Chinese versions of PEPPI $r=0.40$, SER $r=0.40$, and SEE $r=0.39$. There were no correlations with age $r=-0.03$ or disease duration $r=-0.11$.

Conclusion: The ENAT translated well into Chinese and has evidence of validity in KOA. Future studies will further inform its usefulness in clinics, community, and online settings.

Keywords: assessment, educational needs, knee osteoarthritis, instrument validation

\section{Introduction}

Knee osteoarthritis (KOA) is a common disease of the knee joint, which leads to longterm joint pain, limited movement, and poor quality of life in the affected patients. ${ }^{1}$ In the US, $>27$ million adults suffer from KOA. ${ }^{2}$ It is estimated that $10 \%$ of people older than 55 years have disabling knee symptoms due to KOA in the UK. ${ }^{3}$ In China, the incidence of KOA is $13.2 \%$ in $40-70$-year age group. ${ }^{4}$

Patient education is an important aspect of the management of osteoarthritis. The management guidelines for patients with osteoarthritis point out that "patients should receive patient education on their first consultation with health providers". ${ }^{5-7}$ The purpose of patient education is to help patients manage their diseases and improve their life quality. ${ }^{6-8}$ However, research findings have shown that routine patient education struggles to achieve long-term impact on patients; ${ }^{9}$ therefore, individualized, needs-based educational programs that put the patient at the center are advocated. ${ }^{10}$ Understanding the patients' needs for education is a prerequisite in the development of an effective patient-centered education, and some studies have proposed the development of individualized self-management programs for people with osteoarthritis to improve their health status. ${ }^{11,12}$ The European League Against Rheumatism has
Correspondence: Wen Luo The 2nd Ward of Joint Surgery, Tianjin Hospital, 406 Jiefangnan Road, Tianjin 3002 II, China

$\mathrm{Tel}+8622131 \quad 16190054$

Emailw11984@yahoo.com BY NC
hereby accept the Terms. Non-commercial uses of the work are permitted without any further permission from Dove Medical Press Limited, provided the work is properly attributed. For permission for commercial use of this work, please see paragraphs 4.2 and 5 of our Terms (https://www.dovepress.com/terms.php). 
developed evidence-based recommendations, which provide guidance on the delivery of nonpharmacologic interventions of people with hip or KOA. ${ }^{13}$ These include individualized treatment and patient education regarding lifestyle changes, exercise, and other aspects of disease management.

Research on patients' educational needs in patients with arthritis is lacking in China. In the UK, the educational needs assessment tool (ENAT) was developed over 10 years ago ${ }^{14}$ and has been validated in various disease groups. ${ }^{15}$ The ENAT has been shown to help nurses' direct needs-based patient education for people with rheumatoid arthritis (RA). ${ }^{16}$ The ENAT is a simple 39-item questionnaire used to assess educational needs of people with arthritis. It consists of seven domains: pain management (six items), activity (five items), feeling (four items), arthritis course (seven items), treatment (seven items), self-care measure (six items), and support system (four items). Each item has a five-point Likert scale, scored as 0 =not important, $1=$ a little important, 2 =fairly important, 3 =very important, and 4 =extremely important, thus directly reflecting the patients' educational needs. ${ }^{14}$ In the Netherlands, the Dutch version ENAT has been used to determine educational needs of patients with RA, systemic lupus erythematosus, and systemic scleroderma (SSc). ${ }^{17-19}$ In Poland, the Polish version of the tool was validated and used to summarize the educational needs of patients with RA and SSc. ${ }^{20-22}$ The ENAT has been validated for use in osteoarthritis in Austria, the Netherlands, Norway, Portugal, and the UK. ${ }^{15,23}$

Nurses spend a lot of time in patient education, and providing needs-based patient education ensures that this important activity is effective. ${ }^{6,7}$ The ENAT is the tool with which this can be achieved. In China, research on educational needs of patients with arthritis is at an infancy stage and no tools are available for assessment of patients' educational needs. The aim of this study was to adapt the ENAT into Chinese (CENAT) and validate it for use in KOA.

\section{Methods}

\section{Study design}

This was a cross-sectional study that involved two phases: 1) adaptation of the original (English) ENAT into Chinese by researchers from two hospitals in Beijing and Tianjin, between January and February 2016; and 2) testing the validity of the CENAT in patients with KOA.

In Phase II, we included patients who were hospitalized for KOA of Kellgren-Lawrence grade IV by X-ray ${ }^{22}$ and had the ability to complete the questionnaire independently. We excluded patients who were not able to complete the questionnaire, such as those who were unconscious, with severe mental disorders, cognitive dysfunction, or other serious illnesses. Two family doctors oversaw the integrity of the study and three orthopedic surgeons supervised patient recruitment.

\section{The adaptation of the ENAT into Chinese}

The ENAT was translated into Chinese according to an established cross-cultural adaptation methodology described by Beaton et al, ${ }^{24}$ which consists of five stages: initial translation, synthesis of these translations, back-translation, expert committee assessment, and field testing. First, the ENAT was first translated into Chinese by two senior translators, one is a professional bilingual translator and the other is a bilingual translator with medical educational background. Each translator worked out a report (T1 and T2). Second, two translators with medical educational background joined the team to discuss T1 and T2, and then they revised, edited, and summarized the third translation report (T3). Third, translation report (T3) was back-translated by two translators who lived and studied in America for a long time generating two back-translated versions, respectively (BT1 and BT2). Fourth, the expert committee comprising all translators, clinicians, and a methodologist met for discussion and reached a consensus on all translated items. Following this meeting, five patients with severe KOA were recruited to help in a preliminary test to determine the readability and feasibility of the CENAT. The patients evaluated the specific contents of the scale, and in discussion with the staff, they produced a draft CENAT ready for psychometric testing (Table S1).

\section{Validation of the CENAT}

Following the cross-cultural adaptation, the CENAT was given to patients with $\mathrm{KOA}$, and the data were used to test for different types of validity: 1) construct validity using factor analysis; 2) internal consistency; and 3) concurrent validity, assessed by comparing the CENAT data with selfefficacy data (the self-efficacy for exercise, the self-efficacy for rehabilitation, and perceived efficacy in patient-physician interactions [PEPPI]).

While the CENAT data were used for testing its construct validity (using factor analysis) and internal consistency, the concurrent validity testing involved data from other questionnaires, namely the self-efficacy for exercise scale (SEE), the self-efficacy for rehabilitation outcome scale (SER), and the PEPPI scale (PEPPI-10). Patients who consented were given the CENAT and the other questionnaires to complete independently and return to the investigators. 
The SEE is used to measure self-efficacy for exercise. ${ }^{25}$ The English version has a high internal consistency (Cronbach's $\alpha$ coefficient $=0.92$ ). The Chinese version SEE is validated and used in clinical studies. ${ }^{26}$ The Cronbach's $\alpha$ coefficient of the Chinese version SEE is 0.75 . The SER is validated for measuring the patients' confidence in functional exercise after hip and knee replacement surgery. ${ }^{27}$ The Chinese version SER is validated and used in clinical research. ${ }^{28}$ The tool consists of 12 items, and the Cronbach's $\alpha$ coefficient of the Chinese version SER is 0.94. The 10-item PEPPI-10 is used to test patients' confidence level in patient-physician interactions. ${ }^{29}$ The Chinese version of the PEPPI-10 is validated and has been shown to have Cronbach's $\alpha$ coefficient of $0.91 .{ }^{30}$ The ENAT has been validated in seven rheumatic diseases including osteoarthritis ${ }^{31}$ and this study validated its Chinese version (CENAT).

Once returned, the data from the questionnaires were anonymized and entered into a spreadsheet for data cleaning and analysis. The senior author (WL) who was not involved in the data collection undertook the statistical analysis. The statistical tests are detailed in the next section.

\section{Statistical analysis}

In this study, factor analysis was used to validate the Chinese version of ENAT, that is, to find representative factors of the scale. ${ }^{32}$ Kaiser-Meyer-Olkin test assesses the adequacy of the sample for factor analysis, and a value between 0.8 and 1 suggests that the sample is adequate. Principal component analysis and maximum variance method were adopted in this study to extract the main factors that met the requirements (Eigen value component matrix was rotated by maximum variance method, and the rotated matrix variable score was $>0.60$, which was within the factor's range). Cronbach's $\alpha$ coefficient was used to evaluate the internal consistency of the Chinese ENAT. Cronbach's $\alpha$ coefficient of $>0.7$ indicates that the measured scale has good internal consistency. ${ }^{33}$

The correlations between the CENAT and SER, SEE, and PEPPI were also measured to assess the criterionrelated validity of the CENAT. If the data had been normally distributed, the correlations of the three variables were determined by Pearson's correlation coefficient; otherwise, the Spearman's correlation coefficient was used with values of $0.20-0.39,0.40-0.59,0.60-0.79$, and 0.80-1.0 representing weak, moderate, strong, and very strong correlations, respectively. ${ }^{34}$ In RA population, needsbased patient education had an effect on self-efficacy; ${ }^{15}$ therefore, it is plausible to expect that the educational needs would be correlated with self-efficacy (convergent validity) and not correlated with age or disease duration (divergent validity).

Statistical analyses were performed using SPSS 19.0, IBM Corporation, Armonk, NY, USA; 2010. Structural validity was assessed using confirmatory factor analysis with LISREL 8.7, Scientific Software International, Lincolnwood, IL, USA.

\section{Ethical approval}

All procedures performed in studies involving human participants were in accordance with the ethical standards of the institutional and/or national research committee and with the 1964 Declaration of Helsinki and its later amendments or comparable ethical standards. All patients signed an informed consent form and the study was approved by Tianjin Hospital ethics committee.

\section{Results \\ Patient characteristics}

Overall, 200 participants were recruited and four were excluded from the analysis because of missing responses to items in the CENAT. The evaluable population comprised 196 patients with mean age $63.6 \pm 8.7$ years, mean disease duration was 11.5 years, and $57.1 \%$ were women. Other patient characteristics are summarized in Table 1.

\section{Results of the adaptation phase}

During the adaptation process of the ENAT, the researchers encountered unclear concepts, grammar, and idioms that

Table I Patient characteristics $(\mathrm{N}=196)$

\begin{tabular}{ll}
\hline Characteristics & $\begin{array}{l}\text { Mean } \pm \text { SD or } \\
\text { number (\%) }\end{array}$ \\
\hline Age (years) & $63.1 \pm 8.7$ \\
Sex, female & $112(57.1)$ \\
Disease duration (years) & 11.5 \\
Education & \\
$\quad$ Low & $47(24.0)$ \\
$\quad$ Medium & $117(59.7)$ \\
$\quad$ High & $32(16.3)$ \\
PEPPI (range, 0-100) & $74.98 \pm 20.1$ \\
SEE (range, 0-90) & $62.11 \pm 18.4$ \\
SER (range, 0-120) & $90.34 \pm 23.4$ \\
ENAT (range, 0-156) & $88.69 \pm 29.1$ \\
\hline
\end{tabular}

Notes: ${ }^{\text {L }}$ ow $=$ none, primary school, lower-level vocational training, lower-level secondary general education; medium = middle-level vocational training, higherlevel secondary general education; high = higher-level vocational training, academic certification.

Abbreviations: ENAT, educational needs assessment tool; PEPPI, perceived efficacy in patient-physician interactions; SEE, self-efficacy for exercise scale; SER, self-efficacy for rehabilitation. 
were influenced by an English cultural background. Through discussion, the members of the expert committee reached a consensus on the most appropriate terminology to help Chinese participants understand the items. Table S1 presents the results of the back-translation, issues, and agreements for each ENAT item. These results demonstrate that different cultural backgrounds, national conditions, and social systems were taken into account in the adaptation to enable patients' understanding of the items (Figure 1). The Expert Committee believes that the aim of developing an accurate Chinese version of the ENAT has been achieved.

\section{Internal consistency}

The study results showed that the Cronbach's $\alpha$ coefficient of the CENAT was 0.74. Kaiser-Meyer-Olkin measure was 0.9 , suggesting that this dataset was adequate for factor analysis. Common factors with the characteristic value $\geq 1$ were extracted by using principal component analysis and maximum variance rotation method. The results showed that the characteristic values of factor 1 , factor 2 , factor 3 , factor 4 , and factor 5 were $\geq 1$, and the contribution rate was $67.9 \%$, including all 39 items (Table 2). The confirmatory factor analysis showed good-fit indices for a five-factor model of the CENAT $(\mathrm{df}=692, p$-value $<0.01$, root mean square error of approximation $=0.08$ ). The correlation coefficient between the five factors ranged between 0.65 and 0.91 (Figure 2).

\section{Criterion-related validity}

Table 3 presents the Spearman's correlations between the CENAT and other measures. The results showed that the CENAT had weak but significant correlations with the measures of self-efficacy (PEPPI $r=0.40, p<0.001$; SER $r=0.40$,

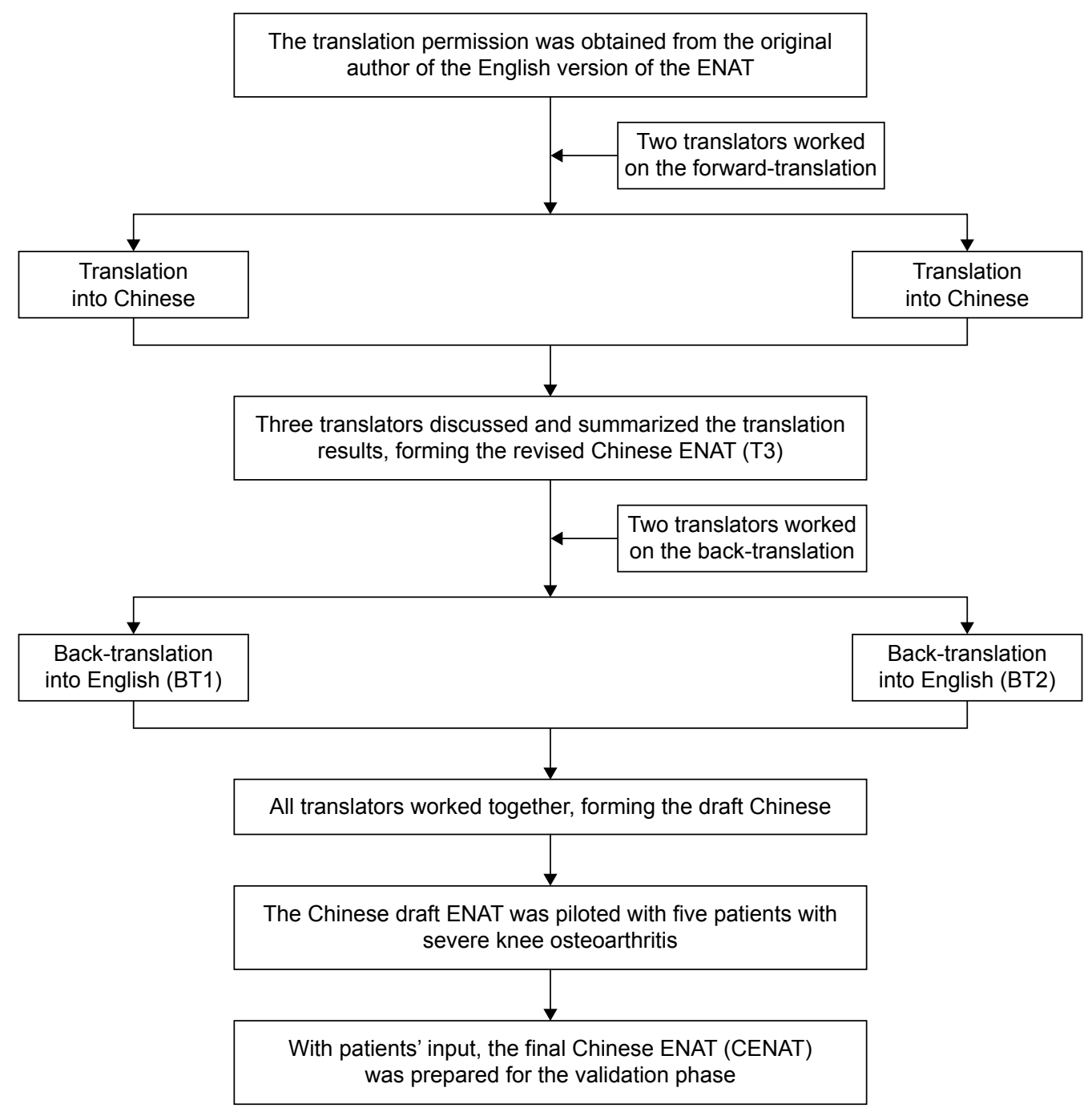

Figure I The process of cross-cultural adaptation of the ENAT into Chinese.

Abbreviations: BTI, back-translation I; BT2, back-translation 2; ENAT, educational needs assessment tool. 
Table 2 Factor analysis of the CENAT rotating element matrix ${ }^{a}$

\begin{tabular}{|c|c|c|c|c|c|}
\hline \multirow[t]{2}{*}{ Item } & \multicolumn{5}{|c|}{ Factor } \\
\hline & $I$ & 2 & 3 & 4 & 5 \\
\hline Pain I & 0.343 & 0.242 & 0.101 & 0.225 & 0.742 \\
\hline Pain2 & 0.369 & 0.094 & 0.195 & 0.634 & 0.267 \\
\hline Pain3 & 0.144 & 0.286 & 0.138 & 0.789 & -0.010 \\
\hline Pain4 & 0.155 & 0.236 & $0.28 I$ & 0.766 & 0.029 \\
\hline Pain5 & 0.030 & 0.213 & 0.110 & $0.75 \mathrm{I}$ & 0.205 \\
\hline Pain6 & 0.155 & 0.010 & 0.222 & 0.668 & 0.348 \\
\hline Movement7 & 0.374 & 0.412 & 0.390 & 0.234 & 0.275 \\
\hline Movement8 & 0.166 & 0.275 & 0.424 & 0.189 & 0.477 \\
\hline Movement9 & 0.182 & 0.516 & 0.227 & 0.225 & $0.44 I$ \\
\hline Movement I0 & 0.469 & 0.254 & 0.226 & 0.389 & 0.346 \\
\hline Movement I I & 0.305 & 0.724 & 0.180 & 0.282 & 0.089 \\
\hline Feeling | 2 & 0.184 & 0.322 & 0.587 & 0.399 & 0.223 \\
\hline Feeling | 3 & 0.398 & 0.168 & 0.614 & 0.435 & -0.019 \\
\hline Feeling | 4 & 0.416 & 0.016 & 0.191 & 0.363 & 0.434 \\
\hline Feeling I5 & 0.336 & 0.071 & 0.601 & 0.413 & 0.135 \\
\hline Disease 16 & 0.187 & 0.505 & 0.199 & 0.188 & 0.582 \\
\hline Disease I7 & 0.463 & 0.446 & 0.377 & 0.249 & 0.255 \\
\hline Disease I 8 & 0.284 & 0.562 & 0.391 & 0.233 & 0.078 \\
\hline Disease 19 & 0.526 & 0.581 & 0.131 & 0.225 & 0.150 \\
\hline Disease20 & 0.373 & 0.328 & 0.331 & 0.258 & 0.315 \\
\hline Disease2I & 0.377 & 0.454 & $0.24 I$ & $0.34 I$ & 0.174 \\
\hline Disease22 & 0.533 & 0.505 & 0.091 & 0.084 & 0.257 \\
\hline Treatment 23 & 0.452 & 0.264 & 0.346 & 0.126 & 0.628 \\
\hline Treatment24 & $0.68 I$ & 0.296 & 0.359 & 0.169 & 0.219 \\
\hline Treatment 25 & 0.650 & 0.399 & 0.144 & 0.091 & 0.259 \\
\hline Treatment26 & 0.662 & 0.259 & 0.377 & 0.219 & 0.113 \\
\hline Treatment 27 & 0.668 & 0.245 & 0.332 & 0.134 & 0.257 \\
\hline Treatment 28 & 0.609 & 0.478 & 0.148 & 0.131 & 0.333 \\
\hline Treatment29 & 0.624 & 0.127 & 0.311 & 0.447 & 0.092 \\
\hline Selfhelp30 & 0.211 & 0.311 & 0.675 & 0.247 & 0.331 \\
\hline Selfhelp3I & 0.340 & 0.318 & 0.513 & 0.316 & 0.209 \\
\hline Selfhelp32 & 0.213 & 0.603 & 0.377 & 0.097 & 0.266 \\
\hline Selfhelp33 & 0.337 & 0.668 & 0.216 & 0.246 & 0.206 \\
\hline Selfhelp34 & 0.279 & $0.74 I$ & 0.212 & 0.118 & 0.215 \\
\hline Selfhelp35 & 0.651 & 0.512 & 0.193 & 0.139 & 0.007 \\
\hline Support36 & 0.272 & 0.333 & 0.673 & 0.155 & 0.269 \\
\hline Support37 & 0.664 & 0.240 & 0.289 & 0.229 & 0.224 \\
\hline Support38 & 0.307 & 0.517 & 0.554 & 0.112 & 0.080 \\
\hline Support39 & 0.685 & 0.343 & 0.136 & 0.118 & 0.269 \\
\hline
\end{tabular}

Notes: Extraction method: principal component. Rotation method: orthogonal

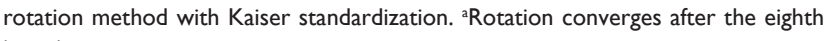
iteration.

Abbreviation: CENAT, Chinese version of the educational needs assessment tool.

$p<0.001$; and SEE $r=0.39 ; p<0.001)$. There were no correlations between the CENAT and age $(r=-0.03, p=0.69)$ nor disease duration $(r=-0.11, p=0.11)$.

\section{Discussion}

In the present study, a standard adaptation method $^{24}$ was used to adapt the ENAT into Chinese, and this process was useful in ensuring the conceptual equivalence between the original (English) ENAT and the Chinese version. Simplistic translation of a questionnaire into another language without cross-cultural adaptation and validation is inadequate. ${ }^{22,35}$ Due to different cultural background, national conditions, and other factors, some items of the Chinese ENAT could not be directly translated into Chinese; therefore, the adaptation process took account of culture to ensure that the concepts contained in the items were meaningful to Chinese patients.

As our purpose was to adapt the ENAT into Chinese and test its validity, the results have confirmed that the CENAT is a valid tool for assessing the educational needs of patients with severe KOA in China. Factor analysis and results of the internal consistency have demonstrated that the ENAT has retained its construct validity after being adapted into Chinese. In chronic disease, self-efficacy has been shown to mediate the effect of patient education. ${ }^{16}$ The presence of correlation between the CENAT and measures of self-efficacy implies a degree of convergent validity, although these were only weak correlations. Care needs to be taken in interpreting these results as the CENAT assesses patient educational need, and this was a noninterventional cross-sectional study, and the level of patients' need does not necessarily correspond to self-efficacy. Conversely, the lack of significant correlation with age and disease duration implies a divergent validity, both of which provide further evidence of the validity of the CENAT in KOA.

The ENAT was designed to assess educational needs of patients with arthritis, and in this study, ${ }^{14}$ we have now demonstrated its validity in Chinese population of patients with KOA. The CENAT can, therefore, be used to direct needs-based education and to develop the health educational programs in patients with KOA in China.

The limitations of this study are that 1) as the sample was selected from hospitalized patients, the risk of selection bias cannot be excluded; 2) we could not undertake more powerful analyses such as item-response theory or exploration of differential item functioning. While those analyses can be carried out in the future, we believe that the current analysis provides preliminary evidence of the validity of the CENAT; 3) being a noninterventional cross-sectional study, the evidence of criterion-related validity was limited and sensitivity to change was not assessed; 4) the CENAT was used in hard copy (paper) form and as the technology of questionnaire moved into electronic forms, its response in online and app forms will need to be assessed; 5) this study validates the CENAT in KOA; therefore, further evidence will be required before the tool is used in other types of osteoarthritis. Despite the abovementioned limitations, 


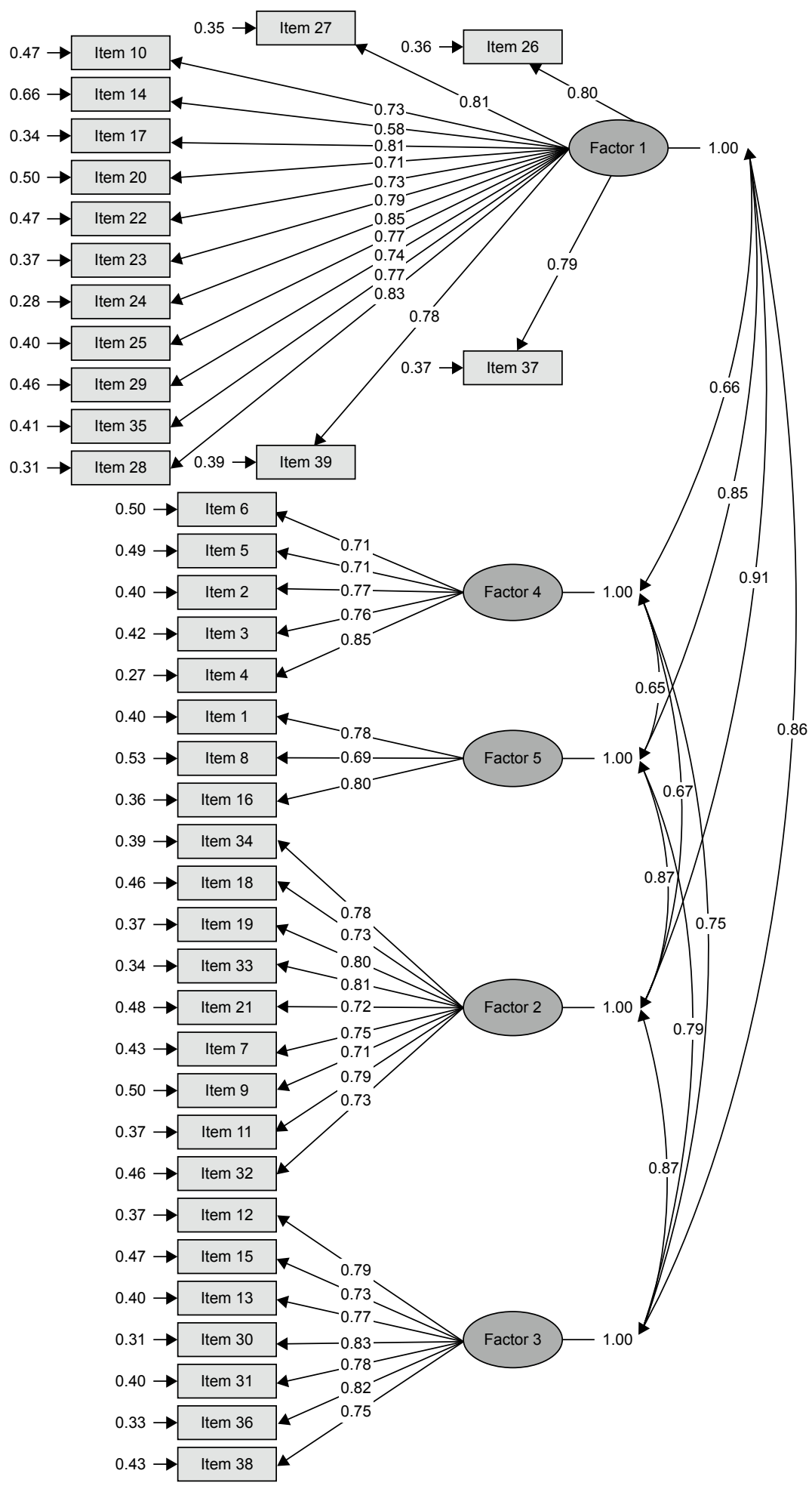

Figure 2 Standardized factor loading and residuals for the items of the Chinese version of educational needs assessment tool.

we believe that our conclusions are well supportive of the validity of the CENAT in this patient population.

\section{Conclusion}

This is the first study to adapt and validate the ENAT into Chinese for use in severe KOA. We systematically investigated the validity of the Chinese version ENAT, showing that the Chinese version ENAT has a good construct validity, internal consistency, and satisfactory criterionrelated validity. Therefore, this tool can help nurses to assess the educational needs of patients with severe KOA and provide effective needs-based patient education. Although 
Table 3 Spearman's correlations between the CENAT and other measures

\begin{tabular}{|c|c|c|c|c|c|c|}
\hline CENAT & ENAT & PEPPI & SER & SEE & $\begin{array}{l}\text { Disease } \\
\text { duration }\end{array}$ & Age \\
\hline \multicolumn{7}{|l|}{ CENAT } \\
\hline Spearman's correlations & I & $0.40 * *$ & $0.40 * *$ & $0.39 * *$ & -0.11 & -0.03 \\
\hline$P$ & & 0.000 & 0.000 & 0.000 & 0.114 & 0.690 \\
\hline$N$ & 196 & 196 & 196 & 196 & 196 & 196 \\
\hline \multicolumn{7}{|l|}{ Bootstrap ${ }^{a}$} \\
\hline Deviation & 0 & -0.003 & -0.002 & -0.000 & 0.005 & 0.000 \\
\hline Standard error & 0 & 0.069 & 0.067 & 0.069 & 0.067 & 0.074 \\
\hline \multicolumn{7}{|l|}{$95 \% \mathrm{Cl}$} \\
\hline Floor & I & 0.251 & 0.264 & 0.249 & -0.239 & -0.178 \\
\hline Ceiling & I & 0.426 & 0.514 & 0.521 & 0.025 & 0.111 \\
\hline
\end{tabular}

Notes: aUnless otherwise noted, bootstrap results are based on I,000 bootstrap samples. $* * p<0.01$.

Abbreviations: CENAT, Chinese version of ENAT; ENAT, educational needs assessment tool; PEPPI, perceived efficacy in patient-physician interactions; SEE, self-efficacy for exercise scale; SER, self-efficacy for rehabilitation.

the scale has demonstrated validity in this study, further research will be required to provide the evidence for other psychometric properties including sensitivity to change.

\section{Disclosure}

The authors report no conflicts of interest in this work.

\section{References}

1. Kandam U, Croft P. Clinical co morbidity in osteoarthritis: associations with physical function in older patients in family practices. J Rheumatol. 2007;34(9):1899-1904.

2. Lawrence RC, Felson DT, Helmick CG, et al; National Arthritis Data Workgroup. Estimates of the prevalence of arthritis and other rheumatic conditions in the United States. Part II. Arthritis Rheum. 2008;58:26-35.

3. Jordan KM, Arden NK, Doherty M, et al; Standing Committee for International Clinical Studies Including Therapeutic Trials ESCISIT. Recommendations 2003: an evidence based approach to the management of knee osteoarthritis: report of a task force of the Standing Committee for International Clinical Studies Including Therapeutic Trials (ESCISIT). Ann Rheum Dis. 2003;62:1145-1155.

4. Tallon D, Chard J, Dieppe P. Exploring the priorities of patients with osteoarthritis of the knee. Arthritis Care Res. 2000;13(5):312-319.

5. Lorig KR, Ritter PL, Lawrent DD, Fries JF. Long-term randomized controlled trials of tailored-print and small-group arthritis self-management interventions. Medical Care. 2004;42:346-354.

6. Zangi HA, Ndosi M, Adams J, et al. European League Against Rheumatism (EULAR). EULAR recommendations for patient education for people with inflammatory arthritis. Ann Rheum Dis. 2015;74(6): 954-962.

7. Ackerman IN, Buchinder R, Osborne RH. Factors limiting participation in arthritis self-management programmers: an exploration of barriers and patient preference within a randomized controlled trial. Rheumatology (Oxford). 2013;52(3):472-479.

8. Warsi A, LaValley MP, Wang PS, Avorn J, Solomon DH. Arthritis self-management education programs: a meta-analysis of the effect on pain and disability. Arthritis Rheum. 2003;48(8):2207-2213.

9. Coulter A, Ellins J. Effectiveness of strategies for informing educating and involving patients. BMJ. 2007;335:24-27.

10. Clayman ML, Pandit AU, Bergeron AR, Cameron KA, Ross E, Wolf MS. Ask, understand, remember: a brief measure of patient communication self-efficacy within clinical encounters. J Health Commun. 2010; 15(Suppl 2):72-79.
11. Hurley MV, Walsh NE, Mitchell HL, et al. Clinical effectiveness of a rehabilitation program integrating exercise, self-management, and active coping strategies for chronic knee pain: a cluster randomized trial. Arthritis Rheum. 2007;57(7):1211-1219.

12. Coleman S, Briffa NK, Carroll G, Inderjeeth C, Cook N, McQuade J. A randomized controlled trial of a self-management education program for osteoarthritis of the knee delivered by health care professionals. Arthritis Res Ther. 2012;14:R21.

13. Femandes L, Hagen KB, Bijlsma WJ, et al; European League Against Rheumatism (EULAR). EULAR recommendations for the nonpharmacological core management of hip and knee osteoarthritis. Ann Rheum Dis. 2013;72:1125-1135.

14. Hardware B, Lacey E, Shewan J. Towards the development of a tool to assess educational needs in patients with arthritis. Clinical Efficacy Nursing. 2004;8:111-117.

15. Ndosi M, Bremander A, Hamnes B, et al. Validation of the educational needs assessment tool as a generic instrument for rheumatic diseases in seven European countries. Ann Rheum Dis. 2014;73(12):2122-2129.

16. Ndosi M, Johnson D, Young T, et al. Effects of needs-based patient education on self-efficacy and health outcomes in people with rheumatoid arthritis: a multicentre, single blind, randomised controlled trial. Ann Rheum Dis. 2016;75(6):1126-1132.

17. Meesters JJ, Vliet Vlieland TP, Hill J, Ndosi ME. Measuring educational needs among patients with rheumatoid arthritis using the Dutch version of the educational needs assessment tool (DENAT). Clin Rheumatol. 2009;28:1073-1077.

18. Schouffoer A, Ndosi ME, Vliet Vlieland TP, Meesters JJ. The educational needs of people with systemic sclerosis: a cross-sectional study using the Dutch version of the Educational Needs Assessment Tool (D-ENAT). Rheumatol Int. 2016;36(2):289-294.

19. Zirkzee EJ, Ndosi ME, Vliet Vlieland TP, Meesters JJ. Measuring educational needs among patients with systemic lupus erythematosus (SLE) using the Dutch version of the Educational Needs Assessment Tool (D-ENAT). Lupus. 2014;23(13):1370-1376.

20. Sierakowska M, Sierakowski S, Sierakowska J, Horton M, Ndosi M. Developing the Polish educational needs assessment tool (Pol-ENAT) in rheumatoid arthritis and systemic sclerosis: a cross-cultural validation study using Rasch analysis. Qual Life Res. 2015;24:721-733.

21. Sierakowska M, Klepacka M, Sierakowski SJ, et al. Assessment of education requirements for patients with rheumatoid arthritis, based on the Polish version of the Educational Needs Assessment Tool (Pol-ENAT), in the light of some health problems - A cross-sectional study. Ann Agric Environ Med. 2016;23(2):361-367.

22. Maiotti M, Monteleone Tarantoin U, Farsciglione GF, Marini S, Coletta M. Correlation between osteoarthritis cartilage damage and levels of proteinases and proteinase inhibitors in synovial fluid from the knee joint. Anhroscopy. 2000;16(5):522-526. 
23. Drăgoi RG, Ndosi M, Sadlonova M, et al. Patient education, disease activity and physical function: can we be more targeted? A cross sectional study among people with rheumatoid arthritis, psoriatic arthritis and hand osteoarthritis. Arthritis Res Ther. 2013;15(5):R156.

24. Beaton DE, Bombardier C, Guillemin F, Ferraz MB. Guidelines for the process of cross-cultural adaptation of self-report measures. Spine (Phila Pa 1976). 2000;25(24):3186-3191.

25. Resnick B, Jenkins LS. Testing the reliability and validity of the selfefficacy for exercise scale. Nurs Res. 2000;49(3):154-159.

26. Lee LL, Oerng SJ, Ho CC, Hsu H-M, Lau S-C, Arthur A. A preliminary reliability and validity studying of the Chinese version of the self-efficacy for exercise scale for older adults. Int J Nurs Stud. 2009; 41:230-238.

27. Waldrop D, Lightsey OR, Ethington CA, Coke AL. Self-efficacy, optimism, health competence and recovery from orthopedic surgery. J Couns Psychol. 2007;48:233-238.

28. Wang HY, Hu YL, Hu SL, Zhou L, Qian Y, Qian HJ. The reliability and validity assessment of the Chinese version rehabilitation self-efficacy scale. Chinese Journal of Modern Nursing. 2014;20(3):268-270.

29. Maly RC, Frank JC, Marsball GN, DiMatteo MR, Reuben DB. Perceived efficacy in Patient-Physician Interactions (PEPPI): validation of an instrument in older persons. J Am Geriatr Soc. 1998;46:889-894.
30. Zhao H, Luo W, Maly RC, Liu J, Lee J, Cui Y. Validation of the Chinese version 10-item perceived Efficacy in patient-physician interactions scale in patients with osteoarthritis. Patient Preference and Adherence. 2016;10:2189-2195.

31. Ndosi M, Tennant A, Bergsten U, et al. Cross-cultural validation of the educational needs assessment tool in RA in 7 European countries. BMC Musculoskeletal Disorders. 2011;12:110.

32. Monticone M, Giorgi I, Baiardi P, Barbieri M, Rocca B, Bonezzi C. Development of the Italian version of the tampa scale of kinesiophobia (TSK-I): cross-cultural adaptation, factor analysis, reliability, and validity. Spine. 2010;35:1241-1246.

33. Crotina JM. What is coefficient alpha? an examination of theory and applications. J Appl Psychol. 1993;78:98-104.

34. Zar JH. Significance testing of the Spearman rank correlation coefficient. J Am Stat Assoc. 1972;67(339):578-580.

35. Acquadro C, Conway K, Hareenlran A, Aaronson N. European regulatory issues and quality of life assessment (ERIQA) group: literature review of methods to translate health-related quality of life questionnaires for use in multinational clinical trials. Value Health. 2008;11(3):509-521. 


\section{Supplementary material}

Table SI Back-translation, issues, and agreements for each educational needs assessment tool item

\begin{tabular}{|c|c|c|c|c|}
\hline Original & $\begin{array}{l}\text { Back-translation I } \\
\text { (BTI) }\end{array}$ & $\begin{array}{l}\text { Back-translation } 2 \\
\text { (BT2) }\end{array}$ & Issues & Agreement \\
\hline $\begin{array}{l}\text { Arthritis educational needs } \\
\text { assessment tool }\end{array}$ & $\begin{array}{l}\text { Assessment tool for } \\
\text { educational needs in } \\
\text { patients with arthritis }\end{array}$ & $\begin{array}{l}\text { The tool for assessing } \\
\text { needs for education in } \\
\text { patients with arthritis } \\
\text { related }\end{array}$ & $\begin{array}{l}\text { Chinese language has } \\
\text { multiple meanings for } \\
\text { the word "arthritis" }\end{array}$ & $\begin{array}{l}\text { 关节炎教育需求评估工具 } \\
\text { “Arthritis" is the most } \\
\text { adequate translation }\end{array}$ \\
\hline $\begin{array}{l}\text { How long have you had your } \\
\text { arthritis for? }\end{array}$ & $\begin{array}{l}\text { How long have you been } \\
\text { diagnosed with arthritis? }\end{array}$ & $\begin{array}{l}\text { How long have } \\
\text { you suffered from } \\
\text { arthritis? }\end{array}$ & $\begin{array}{l}\text { Uncertainty whether } \\
\text { word "diagnosed" or } \\
\text { "suffer" should be used } \\
\text { in the Chinese version }\end{array}$ & $\begin{array}{l}\text { “您因为关节炎病了多久?” } \\
\text { The Chinese translation is } \\
\text { correct in terms of style }\end{array}$ \\
\hline Please state your age in years: & Please state your age & $\begin{array}{l}\text { Please state your age } \\
\text { in years: }\end{array}$ & $\begin{array}{l}\text { Discussion on whether } \\
\text { phrase "in years" is } \\
\text { needed. }\end{array}$ & $\begin{array}{l}\text { “请陈述您的年龄” } \\
\text { The phrase “in years” has } \\
\text { been omitted }\end{array}$ \\
\hline $\begin{array}{l}\text { How old were you when you } \\
\text { left school? }\end{array}$ & $\begin{array}{l}\text { How old were you when } \\
\text { you graduated from } \\
\text { school? }\end{array}$ & $\begin{array}{l}\text { How old were you } \\
\text { when you graduated } \\
\text { from school }\end{array}$ & $\begin{array}{l}\text { Education in the Chinese } \\
\text { system does not require } \\
\text { age information }\end{array}$ & $\begin{array}{l}\text { “您的学历是” } \\
\text { The most appropriate } \\
\text { Chinese phrase was chosen }\end{array}$ \\
\hline $\begin{array}{l}\text { At this time, do you want } \\
\text { education about anything } \\
\text { to help you deal with your } \\
\text { arthritis? }\end{array}$ & $\begin{array}{l}\text { Do you want to get } \\
\text { information which } \\
\text { will help you manage } \\
\text { arthritis? }\end{array}$ & $\begin{array}{l}\text { Do you want to help } \\
\text { yourself to cope } \\
\text { with arthritis by any } \\
\text { obtaining education? }\end{array}$ & $\begin{array}{l}\text { Uncertainty how to } \\
\text { translate into Chinese } \\
\text { "manage" or "cope } \\
\text { with" }\end{array}$ & $\begin{array}{l}\text { “您希望获得应对自身关 } \\
\text { 节炎的信息吗” } \\
\text { Chinese translation is } \\
\text { correct in terms of style }\end{array}$ \\
\hline If yes, what? & $\begin{array}{l}\text { If yes, what information } \\
\text { would you like to get? }\end{array}$ & $\begin{array}{l}\text { If yes, what would you } \\
\text { like to know? }\end{array}$ & $\begin{array}{l}\text { Uncertainty how to } \\
\text { translate into Chinese } \\
\text { "get" or "know" }\end{array}$ & $\begin{array}{l}\text { “如果是, 您想知道什么” } \\
\text { Chinese version is correct } \\
\text { in terms of style }\end{array}$ \\
\hline $\begin{array}{l}\text { In general, how much } \\
\text { information do you want } \\
\text { about your arthritis? }\end{array}$ & $\begin{array}{l}\text { In general, how much } \\
\text { would you like to know } \\
\text { about your arthritis? }\end{array}$ & $\begin{array}{l}\text { In general, how much } \\
\text { information would } \\
\text { you like to get about } \\
\text { your arthritis? }\end{array}$ & $\begin{array}{l}\text { Discussion on whether } \\
\text { word "information" } \\
\text { should be added }\end{array}$ & $\begin{array}{l}\text { “通常, 您想了解多少关 } \\
\text { 于关节炎的知识?” } \\
\text { The word “information” } \\
\text { was added }\end{array}$ \\
\hline $\begin{array}{l}\text { How much do you need to } \\
\text { know now about each of the } \\
\text { following things? }\end{array}$ & $\begin{array}{l}\text { How much do you need } \\
\text { to know now about each } \\
\text { of the following issues? }\end{array}$ & $\begin{array}{l}\text { How much would you } \\
\text { already know about } \\
\text { the following issues? }\end{array}$ & $\begin{array}{l}\text { Discussion concerning } \\
\text { the phrase "Please mark } \\
\text { the appropriate column }\end{array}$ & $\begin{array}{l}\text { “下列问题您想了解多 } \\
\text { 少？请在适当的列表下 } \\
\text { 打勾” }\end{array}$ \\
\hline $\begin{array}{l}\text { Please tick in the column that } \\
\text { shows best how you feel: }\end{array}$ & $\begin{array}{l}\text { Please tick in the column } \\
\text { that shows best how } \\
\text { you feel: }\end{array}$ & $\begin{array}{l}\text { Please mark the } \\
\text { appropriate column } \\
\text { with an " } \sqrt{ } \text { " }\end{array}$ & with $n$ ' $\sqrt{ }$ ”' & $\begin{array}{l}\text { Chinese version is correct } \\
\text { in terms of style }\end{array}$ \\
\hline $\begin{array}{l}\text { Using heat or cold on painful } \\
\text { joints }\end{array}$ & $\begin{array}{l}\text { Treatment of painful } \\
\text { joint by cold or heat }\end{array}$ & $\begin{array}{l}\text { Reduce the pain of } \\
\text { joints by cold or heat }\end{array}$ & $\begin{array}{l}\text { Uncertainty how to } \\
\text { translate into Chinese } \\
\text { "treatment" or "reduce" }\end{array}$ & $\begin{array}{l}\text { “用冷热疗法处理关节 } \\
\text { 疼痛” } \\
\text { The most correct Chinese } \\
\text { phrase has been chosen }\end{array}$ \\
\hline $\begin{array}{l}\text { This section relates to } \\
\text { managing pain }\end{array}$ & Section on managing pain & $\begin{array}{l}\text { Section on dealing } \\
\text { with pain }\end{array}$ & $\begin{array}{l}\text { Discussion on whether } \\
\text { to choose a more formal } \\
\text { way of introducing } \\
\text { section of questions }\end{array}$ & $\begin{array}{l}\text { “疼痛管理相关部分” } \\
\text { A more formal way of } \\
\text { introducing a new section } \\
\text { was chosen }\end{array}$ \\
\hline $\begin{array}{l}\text { How important is it for you } \\
\text { to know more about the } \\
\text { following }\end{array}$ & $\begin{array}{l}\text { How important is it for } \\
\text { you to know more about } \\
\text { the following issues for } \\
\text { you? }\end{array}$ & $\begin{array}{l}\text { How important is it } \\
\text { for you would know } \\
\text { more about the } \\
\text { following issues? }\end{array}$ & $\begin{array}{l}\text { Discussion on a formal } \\
\text { way of asking a question }\end{array}$ & $\begin{array}{l}\text { “知道以下更多的信息对 } \\
\text { 您来说有多重要” } \\
\text { A formal way of asking a } \\
\text { question has been chosen }\end{array}$ \\
\hline Using exercise & Physical exercise & Functional exercise & $\begin{array}{l}\text { Uncertainty whether } \\
\text { "physical" and } \\
\text { "functional" can be used } \\
\text { synonymic }\end{array}$ & $\begin{array}{l}\text { “运动疗法” } \\
\text { The most correct Chinese } \\
\text { phrase was chosen }\end{array}$ \\
\hline $\begin{array}{l}\text { The section relates to } \\
\text { movement }\end{array}$ & $\begin{array}{l}\text { Section on issues related } \\
\text { to movement }\end{array}$ & $\begin{array}{l}\text { Section on issues } \\
\text { related to mobility }\end{array}$ & $\begin{array}{l}\text { Discussion on word } \\
\text { choice between } \\
\text { "movement" and } \\
\text { "mobility" }\end{array}$ & $\begin{array}{l}\text { “活动相关部分” } \\
\text { The most adequate } \\
\text { Chinese version was } \\
\text { chosen }\end{array}$ \\
\hline
\end{tabular}


Table SI (Continued)

\begin{tabular}{|c|c|c|c|c|}
\hline Original & $\begin{array}{l}\text { Back-translation I } \\
\text { (BTI) }\end{array}$ & $\begin{array}{l}\text { Back-translation } 2 \\
\text { (BT2) }\end{array}$ & Issues & Agreement \\
\hline $\begin{array}{l}\text { Ways of doing things which } \\
\text { wear my joints less }\end{array}$ & $\begin{array}{l}\text { Methods of reducing } \\
\text { wear of joints }\end{array}$ & $\begin{array}{l}\text { Ways of relieving } \\
\text { joints }\end{array}$ & $\begin{array}{l}\text { "Wear my joints less" } \\
\text { was repeated in the } \\
\text { Chinese phrase }\end{array}$ & “缓解关节磨损的方法” \\
\hline $\begin{array}{l}\text { Ways to deal with moods or } \\
\text { depression }\end{array}$ & $\begin{array}{l}\text { Ways to alleviate moods } \\
\text { or depressive states }\end{array}$ & $\begin{array}{l}\text { Ways to cope with } \\
\text { moods or depressive } \\
\text { states }\end{array}$ & $\begin{array}{l}\text { Discussion on word } \\
\text { choice between } \\
\text { "alleviate" and "cope } \\
\text { with". Ambiguous } \\
\text { meaning of the term } \\
\text { "moods" }\end{array}$ & $\begin{array}{l}\text { “应对负性情绪或抑郁状 } \\
\text { 态的方法” } \\
\text { The chosen term “negative } \\
\text { emotion” means frequent } \\
\text { changes in mood }\end{array}$ \\
\hline $\begin{array}{l}\text { Why I am feeling down or } \\
\text { depressed }\end{array}$ & $\begin{array}{l}\text { Why do I feel moody or } \\
\text { depressed }\end{array}$ & $\begin{array}{l}\text { Why do I feel } \\
\text { disappointed or } \\
\text { depressed? }\end{array}$ & $\begin{array}{l}\text { Ambiguous meaning } \\
\text { of the phrase "feeling } \\
\text { down" }\end{array}$ & $\begin{array}{l}\text { “为什么我会感到情绪低 } \\
\text { 落或沮丧?” } \\
\text { The chosen term “moody” } \\
\text { relates to feel down }\end{array}$ \\
\hline $\begin{array}{l}\text { What type of arthritis do I } \\
\text { have }\end{array}$ & $\begin{array}{l}\text { What type of arthritis } \\
\text { do I have }\end{array}$ & $\begin{array}{l}\text { What type of arthritis } \\
\text { do I have }\end{array}$ & $\begin{array}{l}\text { Lack of knowledge of } \\
\text { arthritis in Chinese } \\
\text { patients }\end{array}$ & $\begin{array}{l}\text { “我患有哪种关节炎?” } \\
\text { Chinese version is correct } \\
\text { in terms of style }\end{array}$ \\
\hline $\begin{array}{l}\text { How might arthritis } t \text { affect } \\
\text { my children or relatives }\end{array}$ & $\begin{array}{l}\text { What is the effect of the } \\
\text { disease on my children } \\
\text { and family? }\end{array}$ & $\begin{array}{l}\text { Can the disease } \\
\text { affect the lives of my } \\
\text { children and family? }\end{array}$ & $\begin{array}{l}\text { Multiple meaning of } \\
\text { word "affect" }\end{array}$ & $\begin{array}{l}\text { “关节炎对我的孩子和家 } \\
\text { 人会产生什么影响” } \\
\text { The chosen phrase “the } \\
\text { effect of” relates to “affect” }\end{array}$ \\
\hline $\begin{array}{l}\text { Ways my arthritis can be } \\
\text { treated }\end{array}$ & Therapies for arthritis & $\begin{array}{l}\text { The treatment of } \\
\text { arthritis }\end{array}$ & $\begin{array}{l}\text { Uncertain whether } \\
\text { to use the word } \\
\text { "therapies" or } \\
\text { "treatment" in the } \\
\text { Chinese version }\end{array}$ & $\begin{array}{l}\text { “关节炎治疗方法” } \\
\text { The most adequate } \\
\text { Chinese translation was } \\
\text { chosen }\end{array}$ \\
\hline $\begin{array}{l}\text { Ways my arthritis is affecting } \\
\text { me }\end{array}$ & $\begin{array}{l}\text { Ways arthritis is affecting } \\
\text { me }\end{array}$ & $\begin{array}{l}\text { The way of my } \\
\text { arthritis is affecting } \\
\text { me }\end{array}$ & $\begin{array}{l}\text { Multiple meaning of } \\
\text { word "affect" }\end{array}$ & $\begin{array}{l}\text { “关节炎对我造成影响的 } \\
\text { 方式?” } \\
\text { The chosen phrase “the } \\
\text { effect of” relates to “affect” }\end{array}$ \\
\hline $\begin{array}{l}\text { What might happen in the } \\
\text { future }\end{array}$ & $\begin{array}{l}\text { What will happen to me } \\
\text { in the future }\end{array}$ & $\begin{array}{l}\text { How will my } \\
\text { condition change in } \\
\text { the future }\end{array}$ & $\begin{array}{l}\text { The question is open } \\
\text { ended }\end{array}$ & $\begin{array}{l}\text { “在未来, 我的状态将如 } \\
\text { 何改变” } \\
\text { The translation focuses on } \\
\text { patient's condition in the } \\
\text { future }\end{array}$ \\
\hline $\begin{array}{l}\text { This section is about } \\
\text { treatments you may be } \\
\text { receiving from health } \\
\text { professionals. }\end{array}$ & $\begin{array}{l}\text { Section on treatments } \\
\text { that you can receive } \\
\text { from medical } \\
\text { professionals. }\end{array}$ & $\begin{array}{l}\text { Section contains } \\
\text { treatments that the } \\
\text { patient can receive } \\
\text { from nurses and other } \\
\text { health professionals }\end{array}$ & $\begin{array}{l}\text { Lack of a Chinese } \\
\text { equivalent of a term } \\
\text { "health professionals" }\end{array}$ & $\begin{array}{l}\text { “你能得到健康护理工作 } \\
\text { 者治疗的部分” } \\
\text { The chosen phrase } \\
\text { describes the meaning of } \\
\text { “health professionals” }\end{array}$ \\
\hline $\begin{array}{l}\text { How operation might help } \\
\text { me }\end{array}$ & Can surgery help me & Can surgery help me & $\begin{array}{l}\text { Uncertainty how to } \\
\text { translate "operation" } \\
\text { into Chinese }\end{array}$ & $\begin{array}{l}\text { “手术能帮助我吗” } \\
\text { The most adequate } \\
\text { Chinese term was chosen }\end{array}$ \\
\hline $\begin{array}{l}\text { What are the side effects of } \\
\text { my medicines }\end{array}$ & $\begin{array}{l}\text { What are the side effects } \\
\text { of my drugs }\end{array}$ & $\begin{array}{l}\text { Are there any side } \\
\text { effects to the drugs }\end{array}$ & & $\begin{array}{l}\text { “药物的副作用是什么” } \\
\text { Chinese version is correct } \\
\text { in terms of style }\end{array}$ \\
\hline $\begin{array}{l}\text { How aid might help me } \\
\text { (splints, adaptations, collars) }\end{array}$ & $\begin{array}{l}\text { What aid may help me } \\
\text { (orthopedics orthotics, } \\
\text { splints, fixators) }\end{array}$ & $\begin{array}{l}\text { What aids can help } \\
\text { me (orthopedics } \\
\text { orthotics, splints, } \\
\text { fixators) }\end{array}$ & $\begin{array}{l}\text { Difficulty with translating } \\
\text { term "adaptations" and } \\
\text { "collars" }\end{array}$ & $\begin{array}{l}\text { “器具怎么可以帮 } \\
\text { 助我” (骨科矫形器、 } \\
\text { 夹板、固定器) } \\
\text { Descriptive phrases } \\
\text { “adaptations” and “collars” } \\
\text { have been chosen }\end{array}$ \\
\hline $\begin{array}{l}\text { Alternative treatments or } \\
\text { herbal remedies }\end{array}$ & $\begin{array}{l}\text { Conservative treatment } \\
\text { or Chinese traditional } \\
\text { treatment }\end{array}$ & $\begin{array}{l}\text { Conservative } \\
\text { treatment or Chinese } \\
\text { traditional treatment }\end{array}$ & $\begin{array}{l}\text { Multiple meanings of } \\
\text { the phrase "alternative } \\
\text { treatments" and "herbal } \\
\text { remedies" }\end{array}$ & $\begin{array}{l}\text { “保守治疗或中医疗法” } \\
\text { The most adequate } \\
\text { Chinese term has been } \\
\text { chosen }\end{array}$ \\
\hline
\end{tabular}


Table SI (Continued)

\begin{tabular}{|c|c|c|c|c|}
\hline Original & $\begin{array}{l}\text { Back-translation I } \\
\text { (BTI) }\end{array}$ & $\begin{array}{l}\text { Back-translation } 2 \\
\text { (BT2) }\end{array}$ & Issues & Agreement \\
\hline $\begin{array}{l}\text { Foods or vitamins that might } \\
\text { help }\end{array}$ & $\begin{array}{l}\text { Diet or vitamins that } \\
\text { may help }\end{array}$ & $\begin{array}{l}\text { Foods or vitamins } \\
\text { which might help }\end{array}$ & $\begin{array}{l}\text { More formal version } \\
\text { of question in Chinese } \\
\text { should be given }\end{array}$ & $\begin{array}{l}\text { “食物或维生素能带来的 } \\
\text { 帮助” } \\
\text { Chinese version is correct } \\
\text { in terms of style }\end{array}$ \\
\hline Exercises I should be doing & Recommended exercises & $\begin{array}{l}\text { Recommended } \\
\text { exercises }\end{array}$ & $\begin{array}{l}\text { Uncertainty whether the } \\
\text { word "recommended" } \\
\text { should be used }\end{array}$ & $\begin{array}{l}\text { “推荐的运动” } \\
\text { The most adequate } \\
\text { Chinese translation was } \\
\text { chosen }\end{array}$ \\
\hline $\begin{array}{l}\text { How much exercise should I } \\
\text { be doing }\end{array}$ & Amount of exercise & Amount of exercise & $\begin{array}{l}\text { Uncertainty whether the } \\
\text { word "amount" should } \\
\text { be used }\end{array}$ & $\begin{array}{l}\text { “运动量” } \\
\text { The most adequate } \\
\text { Chinese term was chosen }\end{array}$ \\
\hline $\begin{array}{l}\text { Times when I should call the } \\
\text { doctor or nurse }\end{array}$ & $\begin{array}{l}\text { Times when I should } \\
\text { contact a doctor }\end{array}$ & $\begin{array}{l}\text { Situations when I } \\
\text { should consult a } \\
\text { doctor }\end{array}$ & $\begin{array}{l}\text { Uncertainty whether } \\
\text { the word "situations" } \\
\text { is adequate, and } \\
\text { lack of a Chinese } \\
\text { equivalent of the } \\
\text { sentence "Registered } \\
\text { nursing don't provide } \\
\text { consultative services } \\
\text { regarding issues relevant } \\
\text { to the practice of } \\
\text { nursing for outpatients" }\end{array}$ & $\begin{array}{l}\text { “在什么情况下, 我应该 } \\
\text { 看医生?” } \\
\text { Chinese translation is } \\
\text { correct in terms of style }\end{array}$ \\
\hline $\begin{array}{l}\text { Organizations I can get in } \\
\text { touch with about arthritis }\end{array}$ & $\begin{array}{l}\text { Departments which } \\
\text { can help patients with } \\
\text { arthritis }\end{array}$ & $\begin{array}{l}\text { Departments that } \\
\text { can help patients with } \\
\text { arthritis }\end{array}$ & $\begin{array}{l}\text { Lack of a Chinese } \\
\text { equivalent of a } \\
\text { term "Arthritis } \\
\text { Organizations". } \\
\text { Uncertainty whether } \\
\text { "departments" is the } \\
\text { correct translation of } \\
\text { the term "organizations" }\end{array}$ & $\begin{array}{l}\text { “哪些部门可以帮助关节 } \\
\text { 炎患者” } \\
\text { Chinese phrase describing } \\
\text { contacting an organist was } \\
\text { chosen }\end{array}$ \\
\hline $\begin{array}{l}\text { Who I can ask for financial } \\
\text { help }\end{array}$ & $\begin{array}{l}\text { Who can I ask for } \\
\text { financial help }\end{array}$ & $\begin{array}{l}\text { Who can I ask for } \\
\text { financial help }\end{array}$ & $\begin{array}{l}\text { Lack of cultural } \\
\text { equivalence (it is } \\
\text { possible to ask for } \\
\text { financial help in case of } \\
\text { suffering from arthritis) }\end{array}$ & $\begin{array}{l}\text { “我可以向哪里寻求经济 } \\
\text { 帮助?” } \\
\text { Chinese version is correct } \\
\text { in terms of style }\end{array}$ \\
\hline $\begin{array}{l}\text { Where I can find groups who } \\
\text { will help me to cope with } \\
\text { arthritis }\end{array}$ & $\begin{array}{l}\text { Where can I find } \\
\text { support groups for } \\
\text { arthritis }\end{array}$ & $\begin{array}{l}\text { Where can I find } \\
\text { support groups for } \\
\text { people with arthritis }\end{array}$ & $\begin{array}{l}\text { Lack of cultural } \\
\text { equivalence (it is } \\
\text { possible to ask for help } \\
\text { outside the health care } \\
\text { system) }\end{array}$ & $\begin{array}{l}\text { “我在哪里可以得到病友 } \\
\text { 的帮助?” }\end{array}$ \\
\hline $\begin{array}{l}\text { How I can get the most out } \\
\text { of seeing the doctor or nurse }\end{array}$ & $\begin{array}{l}\text { How to make more } \\
\text { effective contacts with } \\
\text { the doctor or nurse }\end{array}$ & $\begin{array}{l}\text { How can I improve } \\
\text { communication } \\
\text { with the doctor or } \\
\text { nurse to maximize } \\
\text { effectiveness }\end{array}$ & $\begin{array}{l}\text { Idiomatic meaning of } \\
\text { the "get the most out } \\
\text { of" can be translated in } \\
\text { various ways in Chinese }\end{array}$ & $\begin{array}{l}\text { “如何提高与医生或护士 } \\
\text { 的交流效果” } \\
\text { Chinese version is correct } \\
\text { in terms of grammar }\end{array}$ \\
\hline
\end{tabular}

Note: Arthritis Educational Needs Assessment Tool, @2013, The University of Leeds; All rights reserved.

Patient Preference and Adherence

\section{Publish your work in this journal}

Patient Preference and Adherence is an international, peer-reviewed, open access journal that focuses on the growing importance of patient preference and adherence throughout the therapeutic continuum. Patient satisfaction, acceptability, quality of life, compliance, persistence and their role in developing new therapeutic modalities and compounds to optimize

\section{Dovepress}

clinical outcomes for existing disease states are major areas of interest for the journal. This journal has been accepted for indexing on PubMed Central. The manuscript management system is completely online and includes a very quick and fair peer-review system, which is all easy to use. Visit http://www dovepress.com/testimonials.php to read real quotes from published authors. 